Creative Commons User License: CC BY-NC-ND

Abstracted by: EBSCOhost, Electronic Journals Service (EJS), Google Scholar, Journal Seek, Scientific Commons,

Food and Agricultural Organization (FAO), CABI and Scopus
Journal of Agricultural Extension

Vol. 23 (2) April, 2019

ISSN(e): 24086851; ISSN(Print); 1119944X

http://journal.aesonnigeria.org

http://www.ajol.info/index.php/jae

Email: editorinchief@aesonnigeria.org

http://eoi.citefactor.org/10.11226/v23i2

\title{
External Factors Affecting Lowland Rice Farmers' use of Chemical Pesticides in Welala Village, Kolaka Timur Regency, Indonesia
}

https://dx.doi.org/10.4314/jae.v23i2.9

\section{Batoa, Hartina}

Department of Agricultural Extension Faculty of Agriculture, University of Halu Oleo, Kampus Hijau Bumi Tridharma Anduonohu, Kendari 93232, Indonesia. Email: hartina batoa@yahoo.co.id, Phone: +6281341533371

\section{Limi, Muhammad Aswar}

Department of Agribusiness Faculty of Agriculture, University of Halu Oleo, Kampus Hijau Bumi Tridharma Anduonohu, Kendari 93232, Indonesia

Corresponding author: aswar agribusiness@yahoo.com, Phone: +62-85259705959

\section{Hamzah, Awaluddin}

Department of Agricultural Extension Faculty of Agriculture, University of Halu Oleo,

Kampus Hijau Bumi Tridharma Anduonohu, Kendari 93232, Indonesia. Email: awal.hamzah@gmail.com, Phone: +62-8114059064

\section{Cahyono, Edi Dwi}

Socioeconomic Department Faculty of Agriculture, University of Brawijaya Malang 65144, Indonesia. Email: edidwicahyono@gmail.com, Phone: +62-8123314987

\section{Arimbawa, Putu}

Department of Agricultural Extension Faculty of Agriculture, University of Halu Oleo,

Kampus Hijau Bumi Tridharma Anduonohu, Kendari 93232, Indonesia. Email: ariembawa kdi@yahoo.com, Phone: +62-8114099093

\section{Yusria, Wa Ode}

Department of Agribusiness Faculty of Agriculture, University of Halu Oleo, Kampus Hijau Bumi Tridharma Anduonohu, Kendari 93232, Indonesia. Email: yusria w@yahoo.com, Phone: +62-81244364627

\section{Gafaruddin, Abdul}

Department of Agribusiness Faculty of Agriculture, University of Halu Oleo, Kampus Hijau Bumi Tridharma Anduonohu, Kendari 93232, Indonesia. Email: gafaruddinabdul95@gmail.com, Phone: +62-81341512970

\section{Abstract}

This study determined the role of farmer institutions and government policies on farmers' behaviour in the use of chemical pesticides. Questionnaire was used in as data collection instrument. The research location was Kolaka Timur (Koltim) Regency that has been cultivating lowland rice since the 1980s and become one of the centres of rice production in Southeast Sulawesi and the majority of the farmers are still dependent on pesticides in pests and diseases controlling in rice plants The population of this study was 273 lowland rice farmers. The sampling technique was by simple random sampling of $20 \%$ of the total population so that the sample size is 55 respondents. Descriptive data analysis, Spearman rank correlation analysis, and multiple regression were conducted with the SPSS program. The results showed that farmers' behaviour in the use of chemical pesticides was not as recommended. External factors that influence the behaviour of farmers in the use of pesticides are 
Creative Commons User License: CC BY-NC-ND

Abstracted by: EBSCOhost, Electronic Journals Service (EJS), Google Scholar, Journal Seek, Scientific Commons,

Food and Agricultural Organization (FAO), CABI and Scopus
Journal of Agricultural Extension

Vol. 23 (2) April, 2019

ISSN(e): 24086851; ISSN(Print); 1119944X

http://journal.aesonnigeria.org

http://www.ajol.info/index.php/jae

Email: editorinchief@aesonnigeria.org

http://eoi.citefactor.org/10.11226/v23i2

the role of farmer institutions in making group rules and so the existence of

government policies as the use of chemical pesticides guidelines is recommended.

Keywords: Farmers' behaviour, pesticides utilization, lowland rice, food security

\section{Introduction}

The availability of food to achieve food self-sufficiency is negatively impacted by excessive use of inputs, especially in the use of chemical pesticides. The issue of food security and environmental sustainability is the topic of discussion regarding food fulfilment. Rice is a staple food, so this commodity is included in strategic commodities and even as a political commodity. This can be seen from the government's role in determining policies on rice prices in order to maintain harmonization between farmers as producers with consumers (Hermanto, 2017). Besides the availability factor of food (rice), food safety is also a very important factor in achieving national food security. Rice crops are very vulnerable to the use of chemicals, especially in controlling pests and diseases. Farmers use of chemical pesticides on rice crops is to avoid the risk of crop failure (Interview with Pak Wayan Sunarda, (2018).

The impact of exposure to pesticides on humans is harmful to the fetus and or child, such as cancer in children with parents who are exposed to pesticides because of their work (Stadlinger et al, 2013; Yuantari et al, 2015; Jallow et al, 2017; Bhandari et al, 2018). WHO data shows that $500,000-1,000,000$ people around the world per year have experienced pesticide poisoning and around 500-1,000 people per year experience fatal effects such as cancer, disability, infertility and liver disorders (Yuantari et al, 2015). Excessive chemical impacts cause, loss of natural enemies, and so the occurrence of epidemics of pests and diseases in rice crops (Sumarno and Suyamto, 2014). In addition, extensive and inefficient use of pesticides over the past few decades have resulted in serious soil and water contamination that causes toxic effects on organisms (Liu, et al., 2018). In the case of farmers in herbicide use, the results of the study by Olughu et al (2019) state that most farmers have a moderate level of knowledge and poor practices regarding herbicide use are likely to have an impact on crops and the health of farmers.

Several previous studies have been conducted related to factors that influence the farmers in the use of chemical pesticides such as the research of Jaya (2017), Eliza et al (2013), Damalas and Koutroubas (2018), Akter et al (2018) that several factors such as; the level of education, knowledge, experience, farmer perceptions of locus of control, household income, level of business profit, self-efficacy, and lack of training affect farmers' behaviour in pesticides use. These factors are related to the farmers' personal factors, farmers' external factors and their effects on farmers' behaviour in the use of pesticides have not been widely studied.

Rice farmers have been incorporated into a farmer institution, namely a farmer group. The existence of farmer groups functions as a place to learning, collaboration forum, and farming unit. The existence of farmer institutions can play a role in educating farmers to conduct environmentally friendly and as a liaison for input, capital, and marketing institutions in supporting agricultural development (Arimbawa, 2013; Prawiranegara, 2016). According to Liliweri (2014), agricultural institutions are norms or habits that are structured and patterned and practiced continuously to meet the needs of community members who are closely related to livelihoods from agriculture in the countryside. Based on this statement, the existence of farmers' institutions can play a role in regulating the use of production inputs for the members of the farmer group. 
Creative Commons User License: CC BY-NC-ND

Abstracted by: EBSCOhost, Electronic Journals Service (EJS), Google Scholar, Journal Seek, Scientific Commons,

Food and Agricultural Organization (FAO), CABI and Scopus
Journal of Agricultural Extension

Vol. 23 (2) April, 2019

ISSN(e): 24086851; ISSN(Print); 1119944X

http://journal.aesonnigeria.org

http://www.ajol.info/index.php/jae

Email: editorinchief@aesonnigeria.org

http://eoi.citefactor.org/10.11226/v23i2

Another factor that can be used by farmers as a guideline in crop cultivation is the government's policy on the use of pesticides. The existence of government regulations regarding the use of Pesticides, namely Government Regulation Number 7 of 1973 and Act No. 12 of 1992 concerning Plant Cultivation System. According to that rule, pesticides are chemical substances or compounds, regulating substances and growth stimulants, other substances, and microorganisms, or viruses that are used to protect plants while taking into account sustainability. Therefore, this rule should be based for all stakeholders in use pesticides for each crop cultivation activity, including in rice cultivation. A study by Prawiranegara (2016) shows that $53 \%$ of farmers are unaware of policies in agriculture, while others know. Among farmers who have known about the policies, they feel very helped by the policy in supporting the development of their commodities. Government policies can provide guidance on behavior and security and certainty for farmers in managing their farming. Therefore, the purpose of this study is to determine the behavior of farmers and external factors that influence farmers in the use of chemical pesticides in lowland rice farming.

\section{Methodology}

This study used questionnaire as an instrument for data collection. Research location was Welala Village, Kolaka Timur (Koltim) Regency because farmers have been cultivating lowland rice crops since the 1980s in the area and it is one of the centres of rice production. The research period is 4 months, that is June to October 2018. The population of this research is lowland rice farmers who are members of farmer institutions (farmer groups). The total population is 273 farmers. The sampling technique was simple random sampling of $20 \%$ of the total population that gave the number of samples as 55 farmers.

All selected samples were given questionnaires facilitated by an administrator of farmer group. Data analysis was achieved with rank spearman correlation analysis and multiple regression analysis using the SPSS softwate.

\section{Results and Discussion}

\section{Role of Farmer Institutions}

Table 1 shows that the majority $(74.55 \%)$ of the farmers assume that farmer groups have less role in the activities of lowland rice farming. Farmer groups do not help farmers in getting pesticides. Farmers get pesticides by buying at medicine kiosks surrounding the village. Besides that, there are no rules of the group to using pesticides. Group rules that exist only set the time or schedule of planting and the types of varieties that will be planted in the next planting season. The absence of group rules makes control of pests and diseases based on farmers' own experiences. The local agriculture extension agent provides extension/ counselling through farmer groups on how to control pests and diseases that are environmentally friendly to the farmers, but not all farmers follow the instructions of the extension agent.

\section{Table 1: Role of farmer groups in lowland rice farming}

\begin{tabular}{clc}
\hline No & \multicolumn{1}{c}{ Role of farmers group } & $\%$ \\
\hline 1. & Very important role & 1.82 \\
2. & Play a role & 18.18 \\
3. & Less role & 74.55 \\
4. & No role & 5.45 \\
\hline
\end{tabular}

Source: Processed Primary data, 2018 
Creative Commons User License: CC BY-NC-ND

Abstracted by: EBSCOhost, Electronic Journals Service (EJS), Google Scholar, Journal Seek, Scientific Commons,

Food and Agricultural Organization (FAO), CABI and Scopus
Journal of Agricultural Extension

Vol. 23 (2) April, 2019

ISSN(e): 24086851; ISSN(Print); 1119944X

http://journal.aesonnigeria.org

http://www.ajol.info/index.php/jae

Email: editorinchief@aesonnigeria.org

http://eoi.citefactor.org/10.11226/v23i2

This is due to the absence of group rules so that there are no sanctions against farmers who use pesticides excessively. The absence of group rules related to group leadership (farmer contact). Farmer contacts are people who are responsible in groups for upholding group rules. The absence of group rules in the use of pesticides indicates that farmer contacts pay less attention to the use of pesticides for group member farmers in lowland rice farming. The results by Putra et als (2016) study that the level of application of technology on shallot farming by farmers was influenced by the role of farmer and agricultural extension contacts. This means that the existence of farmer contacts and agricultural extension agents still has an important role in the development of farming. Farmer respondents also get guidance on pest and disease control from government and private agricultural extension agents.

Private extension agents are considered more often to assist the farmers in conducting plant cultivation and pests and diseases control. The private extension agents are the agents of production facilities (agricultural medicines or pesticides) assigned by the company to socialize and promote their products to the farmers. This is in accordance with the results of Olughu et al (2019) that herbicide use by farmers who are not recommended is caused by a lack of knowledge of farmers in using herbicides requiring contact with extension agents, so that farmers receive information and training from extension agents on use the right herbicide. According to Cahyono and Agunga (2016) that the existence of information and communication technology (ICT) can be used by farmers in communicating innovation to farmers. Communication innovations such as the use of pesticides at the farmer level can be done by using ICT in a farmers group. The existence of farmer groups is very important in supporting the fulfilment of the need for food (rice) that is safe for consumption. The results of the research by Limi et al (2018) that local institutions have a strategic role in facilitating farmers to increase production capacity for food needs fulfilling.

\section{Chemical Pesticides Use Policy}

Table 2, Shows that the majority of farmer respondents were aware of government regulations regarding the use of chemical pesticides in lowland rice farming. However, there are also lowland rice farmers who do not know any of these rules. Farmers know the rules for using pesticides from agricultural extension agents as well as from group meetings attended by extension agents and other fellow farmers. The existence of farmer groups and agricultural extension agent as a place for learning farmers is still hoped for farmers.

Table 2: Farmers' knowledge of government policies in the use of chemical pesticides in lowland rice.

\begin{tabular}{clc}
\hline No & Knowledge of policies / rules for using production inputs & $\%$ \\
\hline 1. & Really know the rules of the right pesticide use & 9.09 \\
2. & Know the rules of the right pesticide use & 63.64 \\
3. & Knowles the rules of the right pesticide use & 16.36 \\
4. & Do not know the rules of the right pesticide use & 10.91 \\
\hline
\end{tabular}

Source: Processed Primary data, 2018

This is supported by the results of a study by Fan et al (2015); Damalas et al (2017) and Olughu et al (2019) that government assistance is still needed (in this case agricultural extension agent) so that farmers get knowledge about how to use the right herbicides and non-governmental organizations in the form of loans and subsidies for farmers to apply herbicides with the right amount for effective weed control. Stadlinger et al (2013) shows that poor pesticide handling practices and risk-awareness among African farmers puts human health and the environment at 
Creative Commons User License: CC BY-NC-ND

Abstracted by: EBSCOhost, Electronic Journals Service (EJS), Google Scholar, Journal Seek, Scientific Commons,

Food and Agricultural Organization (FAO), CABI and Scopus
Journal of Agricultural Extension

Vol. 23 (2) April, 2019

ISSN(e): 24086851; ISSN(Print); 1119944X

http://journal.aesonnigeria.org

http://www.ajol.info/index.php/jae

Email: editorinchief@aesonnigeria.org

http://eoi.citefactor.org/10.11226/v23i2

risk. Poor governmental importation practices and unregulated private imports indicate serious weakness in the management of pesticide importation in Zanzibar. Sankoh et al (2016) showed that that a wide range of pesticides are used by rice farmers in Sierra Leone with $60 \%$ of the pesticides used entering the country illegally. Most farmers have no knowledge about the safe handling of pesticides as $71 \%$ of them have never received any form of training.

\section{Farmers' Behaviour in the Use of Chemical Pesticides}

The behaviour of farmers in the use of chemical pesticides is seen from the actions of farmers using pesticides for pest control in rice crops. The farmer's actions are seen from the time, frequency and dose of use. Based on the study results (Table 3) it was found that in terms of the time of pest and disease control, more of the respondent farmers $(58.18 \%)$ sprays as recommended. As for the frequency and dosage of chemical pesticide use, most farmers (above $60 \%$ ) indicated less or not as recommended. Farmers who carry out pest control based on the recommended time do so in the morning with prior observations of plants in advance to see whether there are symptoms of an attack or not on rice crops. If it is seen that there are new insect pests, the farmers will spray on the lowland rice crops. Whereas farmers who do not pay attention to the recommendations for spraying time conduct pest control on a scheduled basis once a week without first seeing the presence or absence of symptoms of pest and disease that attacks on rice plants planted. The differences in farmer's behaviour in the use of pesticides in terms of time, frequency and dosage are related to farmers' knowledge about the dangers of pesticides. Damalas and Koutrobas (2018) stated that the level of knowledge and awareness of farmers about the risk of pesticides is very important in improving security in all aspects of handling pesticides. Knowledge is related to the understanding of concepts while consciousness is not related to knowledge but attitude. For this reason, farmer's behaviour in maintaining safety for the use of pesticides is influenced by perceptions, attitudes, and abilities. Result from studies cotton farmers in Cina by Liu and Huang (2013) find that farmers who are more risk averse use greater quantities of pesticides. Farmers behave in a loss averse manner in the health domain and place more weight on the importance of health over money in the loss domain.

\section{Table 3: Use of chemical pesticides by farmers}

\begin{tabular}{llccc} 
& & \multicolumn{3}{c}{ Farmer $\begin{array}{c}\text { Behaviour Indicators in the Use of } \\
\text { Chemical Pesticides }\end{array}$} \\
\cline { 3 - 5 } No & \multirow{3}{*}{ Category } & Time & Frequency & Dose \\
\cline { 3 - 5 } & & $(\mathrm{n}=55)$ & $(\mathrm{n}=55)$ & $(\mathrm{n}=55)$ \\
\cline { 3 - 5 } & & 58.18 & $\%$ \\
\hline 1. & As recommended & 14.55 & 21.82 \\
2. Sometimes as recommended & 29.09 & 18.18 & 14.55 \\
3. & Less as recommended & 10.91 & 41.82 & 36.36 \\
4. & Not as recommended & 1.82 & 25.45 & 27.27 \\
\hline
\end{tabular}

Source: Processed Primary data, 2018

Based on the frequency of chemical pesticide use, farmers spray between 7-8 times per season $(25.45 \%)$. Farmers consider that repetitive and scheduled spraying could prevent lowland rice crops from attack by pests and diseases which can damage the plants. The dose for using chemical pesticides is not appropriate with the recommendations of agricultural extension agents. The recommended dosage by local agricultural extension agents is from 0.4 to 1.5 litres/ha, while farmers use pesticides more than 3 litres/ha. This indicates excessive use of doses by farmers in the hope that plant pests can die immediately after spraying. Farmers already know the dosage of 
Creative Commons User License: CC BY-NC-ND

Abstracted by: EBSCOhost, Electronic Journals Service (EJS), Google Scholar, Journal Seek, Scientific Commons,

Food and Agricultural Organization (FAO), CABI and Scopus
Journal of Agricultural Extension

Vol. 23 (2) April, 2019

ISSN(e): 24086851; ISSN(Print); 1119944X

http://journal.aesonnigeria.org

http://www.ajol.info/index.php/jae

Email: editorinchief@aesonnigeria.org

pesticide use from extension agents and from the label for pesticides packaging, but most farmers add doses to ensure pests and diseases that attack rice crops dead as soon as. The study at vegetable farmer by Bhandari et al, (2018) show that pesticides and insecticides, especially pyrethrins and pyrethroids as well as organophosphate, were the most frequently used. The average type of pesticide used by farmers in one spraying operation was two types of pesticides with a range of uses of 1-4 types of pesticides. The use of more than one type of pesticide in one spraying by farmers aims to be able to eradicate different pests/diseases. Most farmers experienced headaches and itching. Some of them admitted that the cause of a headache they experienced was by frequent inhalation of chemicals. The impact of using pesticides can cause disruption to human health. Samosir et al (2017) reported that pesticide exposure has an impact on the health of farmers in the form of poisoning, blood concentration levels are abnormal and have a balance disorder.

\section{Some External Factors that Influence Behaviour of Farmers in the Use of Chemical Pesticides}

The behaviour of farmers in the use of pesticides is related to the role of farmer institutions (farmer groups) and government policies. Based on correlation analysis, the role of farmer groups in making group rules is significantly related to farmer's behaviour in the use of chemical pesticides with a correlation value of 0.409 ; while government policy factors have a significant relationship with the role of groups and farmer behaviour in the use of doses with a correlation value of 0.431 and 0.322 . The results of the regression analysis also show that there is a similar effect between government policy and farmer behaviour in the use of pesticides to the value of alpha $(0,03<$ $0,05)$. Judging from these, the t-count value is greater than the t-table value $(2,207>1,678)$. A significant influence/real also takes place between the role of farmer groups against farmer behaviour in the use of pesticides $(0.015<0.05)$. Judging that $t$-count value is greater than the ttable value $(2.518>1.678)$, and the significant effect between government policy and the role of the group with the alpha value $(0.001<0.05)$.and the $t$-count value is greater than the table value $(3.428>1.678)$. The results of the correlation between the role of groups, government policies and the behaviour of farmers in the use of production inputs can be illustrated in Figure 1.

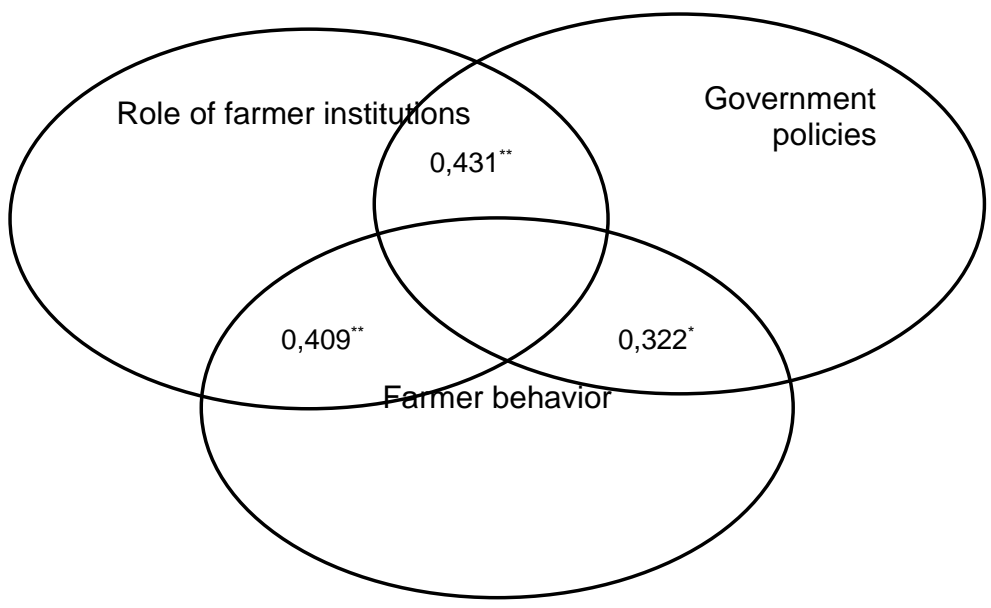

Figure 1: Interlinking between the role of farmer institutions, government policies and farmer behaviour in the use of production inputs 
Creative Commons User License: CC BY-NC-ND

Abstracted by: EBSCOhost, Electronic Journals Service (EJS), Google Scholar, Journal Seek, Scientific Commons,

Food and Agricultural Organization (FAO), CABI and Scopus
Journal of Agricultural Extension

Vol. 23 (2) April, 2019

ISSN(e): 24086851; ISSN(Print); 1119944X

http://journal.aesonnigeria.org

http://www.ajol.info/index.php/jae

Email: editorinchief@aesonnigeria.org

http://eoi.citefactor.org/10.11226/v23i2

The relationship between the three factors as indicated in Figure 1 shows that government policy in the use of pesticides is a concern to farmers in group activities to implement these rules to the group members. The manifestation of the implementation of government policy is that farmers who are members of farmer groups through assistance by extension agents make group's rules about the procedures for using pesticides through group meetings to be mutually agreed upon. The rule is the basis for each member of the farmer group in pests and diseases control in lowland rice crops.

Based on the findings of the research that farmers' behaviour in the use of chemical pesticides is not in accordance with recommended recommendations. Farmers' behaviour in the use of chemical pesticides is influenced by the role of farmer groups and the existence of government policies. The role of farmer institutions/farmer groups in the study area had minimum influence. It can be seen from the absence of group rules in the use of pesticides in the control of pests and diseases of rice crops. The result is that most farmers use pesticides beyond the threshold of both the frequency and dosage used. Farmers believe that the use of chemicals for pest and disease control is very effective. Mustikarini et al (2014) showed that farmers were satisfied with the use of pesticides and there was a positive correlation between the frequency of pesticide use and farmers' loyalty to using pesticides. According to Adomako et al (2015), reliance on chemical agriculture to increase production threatens environmental sustainability. Farmers already know the impact of excessive use of chemicals on grain/rice produced. Most farmers complaint about frequent headaches and itching and other illnesses are believed by farmers themselves to be due to frequent exposure to chemicals (pesticides). But farmers prefer to avoid the risk of crop failure due to pest attacks rather than production security. Yuantari et al (2015) stated that the behaviour of excessive use of pesticides can cause various chronic diseases due to the routine use of pesticides that are still difficult to detect.

The government policy regarding the use of pesticides has not been implemented at the farm level. The link between government policies and the institutional role in making group rules in the use of chemical pesticides can influence farmers' behaviour to use pesticides wisely. Regulations made by the government can be used as a reference by farmer groups to make rules at the group level on how to use chemical pesticides wisely as a guideline for farmers to use pesticides in pests and diseases control in lowland rice plants. Rules made by groups need to be accompanied by enforcement of sanctions for farmers who violate these rules. According to Ville et al (2017) cooperation between formal and informal institutions is needed in the implementation of policies in the food production system for the domestic sector. The conditions in the study area indicate that government regulations did not work effectively. At the farmer group level, there is no regulation on the use of pesticides for its members, so farmers use chemical pesticides according to their respective experiences which tend to exceed the recommended dosage. This is very dangerous because excessive use of chemical pesticides can have an impact on the quality of grain or rice produced and the direct impact on farmers' health itself and so impact the environment. According to Wilkinson et al (2015) strengthening local institutions (farmer groups) can play a role in delivering information or knowledge to local communities. So according to Wilkinson, local institutions can be used by policymakers and development actors as knowledge repositories.

In the research area, there are a small number of farmers who have used organic pesticides, but their goals are only to increase plant hormones. Organic pesticides in the research area are less available and farmers are less interested. The results of Praditya and Syafrial (2017) show that price factors, product availability, product effectiveness, and farmer awareness influence farmers' 
Creative Commons User License: CC BY-NC-ND

Abstracted by: EBSCOhost, Electronic Journals Service (EJS), Google Scholar, Journal Seek, Scientific Commons,

Food and Agricultural Organization (FAO), CABI and Scopus
Journal of Agricultural Extension

Vol. 23 (2) April, 2019

ISSN(e): 24086851; ISSN(Print); 1119944X

http://journal.aesonnigeria.org

http://www.ajol.info/index.php/jae

Email: editorinchief@aesonnigeria.org

http://eoi.citefactor.org/10.11226/v23i2

decision to use organic pesticides. The fact that there are no sanctions for excessive use of pesticides cause farmers not to pay attention to the use of pesticides wisely. If consumers uses the level of chemicals (content) to determine the price of buying grain/rice, it is possible that farmers will pay attention to the use of pesticides.

\section{Conclusion and Recommendations}

Farmer's behavior in the use of chemical pesticides is not in accordance with the recommendation. External factors that influence farmers' behavior in the use of chemical pesticides are the role of farmer institutions and the existence of government policies. Therefore, in changing the behavior of farmers in excessive use of chemical pesticides, the synergy between the government as a policymaker with farmer institutions in making group rules regarding the use of chemical pesticides is needed. Besides, other agribusiness actors such as institutions are expected to play a role in changing the farmers' behavior in excessive use of chemicals by only buying grain/rice from farmers with fixed levels of chemical residue.

\section{Acknowledgments}

We thank Halu Oleo University that provided research grants through DIPA BLU UHO 2018 so that this research can be carried out in accordance with its intended purpose.

\section{References}

Adomako, Theophilus and Ampadu, Boateng., (2015). The Impact of Agricultural Practices on Environmental Sustainability in Ghana: A review. Journal of Sustainable Development, 8 (8): 70-85.

Akter, M., Liangxin F., Md. Mokhesur R., V. Geissen, and Coen J. Ritsema. (2018). Vegetable Farmers' Behavior and Knowledge Rrelated to Pesticide Use and Related Health Problem: A Case Study from Bangladesh. Journal of Cleaner Production. Doi:10.1016/j.jclepro.2018.07.130.

Arimbawa, P., (2013). Peran Kelembagaan Agribisnis dalam Usahatani Kakao. Agriplus, 23 (3): 149-154.

Bhandari, G., Atreya, K., Yang, X., Fan, L., Geissen, V. (2018). Factors Affecting Pesticide Safety Behaviour: The Perceptions of Nepalese Farmers and Retailers. Science of The Total Environment. Volumes 631-632, 1 August 2018, Pages 1560-1571. https://doi.org/10.1016/j.scitotenv.2018.03.144

Cahyono, E.D., and Agunga, R., (2016). Policy and Practice of Participatory Extension in Indonesia: A Case Study of Extension Agents in East Java Province. Journal of Agricultural and Extension Education, 23 (3): 38-57.

Damalas, C.A and Khan, M. (2017). Pesticide Use in Vegetable Crops in Pakistan: Insights Through an Ordered Probit Model. Crop Protection. 99 (9) 2017, p59-64. https://doi.org/10.1016/j.cropro.2017.05.004

Damalas, C.A., and S.D. Koutroubas. (2018). Farmers' Behavior in Pesticide Use: A Key Concept for Improving Environmental Safety. Current Opinion in Environmental Science \& Health, Accepted Manuscript. Doi: 10.1016/j.coesh.2018.07.001. 
Creative Commons User License: CC BY-NC-ND

Abstracted by: EBSCOhost, Electronic Journals Service (EJS), Google Scholar, Journal Seek, Scientific Commons,

Food and Agricultural Organization (FAO), CABI and Scopus
Journal of Agricultural Extension

Vol. 23 (2) April, 2019

ISSN(e): 24086851; ISSN(Print); 1119944X

http://journal.aesonnigeria.org

http://www.ajol.info/index.php/jae

Email: editorinchief@aesonnigeria.org

http://eoi.citefactor.org/10.11226/v23i2

Eliza T., Hasanuddin T., and Situmorang S., (2013). Perilaku Petani dalam Penggunaan Pestisida Kimia (Kasus Petani Cabai di Pekon Gisting Atas Kecamatan Gisting Kabupaten Tanggamus). JIIA, 1 (4): 334-342.

Fan, L., Niu, H., Yang, X., Qin, W., Bento, C.P.M., Ritsema, C.J., Geissen, V. (2015). Factors Affecting Farmers' Behaviour in Pesticide Use: Insights from a Field Study in Northern China. Science of The Total Environment. 537, 15 December 2015, p360-368. https://doi.org/10.1016/j.scitotenv.2015.07.150

Hermanto, Saptana. (2017). Rice Price Policy Reviewed from the Dimensions of Price Diterminations. Forum Penelitian Agro Ekonomi, 35 (1): 31-43.

Jallow, M.F.A., Awadh, D.G., Albaho, M.S., Devi, V.Y., Thomas, B.M. (2017). Pesticide risk behaviors and factors influencing pesticide use among farmers in Kuwait. Science of The Total Environment. 574, 1 January 2017, p490-498. https://doi.org/10.1016/j.scitotenv.2016.09.085

Jaya, Kasman., (2017). Peran Pengetahuan, Locus of Control dan Sikap Terhadap Perilaku Petani Bawang Merah Dalam Pengendalian Hama di Kabupaten Sigi. Jurnal Agrotech, 8 (1): 1-7.

Liliweri Alo. (2014). Sosiologi dan Komunikasi Organisasi. Bumi Aksara. Jakarta

Limi, M.A., Arimbawa, P., Budiyanto, Rahma, N., and Cahyono, E.D., (2018). The Roles of Local Institutions to Improve Farmer Access to Foods and Production Capacities. WSEAS Transactions on Business and Economics, 15: 488-494.

Liu, E.M., and Huang, J., (2013). Risk Preferences and Pesticide Use by Cotton Farmers in China. Journal Of Development Economics, 103: 202-2015. https://doi.org/10.1016/j.jdeveco.2012.12.005

Liu, Y., Lonappan, L., Brar, S.K., and Yang S., (2018). Impact of Biochar Amendment in Agricultural Soils on the Sorption, Desorption, and Degradation of Pesticides: A review. The science of the Total Environment, 645:60-70.

Mustikarini F., Retnaningsih, and Simanjuntak M., (2014). Kepuasan dan Loyalitas Petani Padi Terhadap Pestisida. IIm. Kel. \& Kons., 7 (2): 93-102.

Olughu, F.C., Asadu, A.N., Okoro, J.C., and Ozioko, R.I., (2019). Use of Herbicides Among Rural Women Farmers in Abia State, Nigeria. Journal of Agricultural Extension, 23 (1): 171-182.

Praditya, N.Y., and Syafrial. (2017). Analisis Faktor-Faktor Keputusan Pembelian Petani Padi Terhadap Produk Pestisida Nabati. Jurnal Ekonomi Pertanian dan Agribisnis (JEPA), 1 (2):108-118.

Prawiranegara, Darojat. (2016). Penguatan peran Kelembagaan Petani dalam Peningkatan Kapabilitas Petani Mengelola Inovasi Berbasis Teknologi Informasi. Disertasi. Pascasarjana Institut Pertanian Bogor. Bogor.

Putra, E.A.S., Witjaksono, R., and Harsoyo. (2016). The Role of Chairman of Farmer Groups in Red Onion Cultivation Technology Adoption in the Sandy Beach Land of Sanden Subdistrict of Bantul District. Agro Ekonomi, 27 (2): 150-164.

Samosir, Kholilah., O. Setiani, and Nurjazuli. (2017). Hubungan Pajanan Pestisida Dengan Gangguan Keseimbangan Tubuh Petani Hortikultura di Kecamatan Ngablak Kabupaten Magelang. Jurnal Kesehatan Lingkungan Indonesia, 16 (2): 63 - 69. 
Creative Commons User License: CC BY-NC-ND

Abstracted by: EBSCOhost, Electronic Journals Service (EJS), Google Scholar, Journal Seek, Scientific Commons,

Food and Agricultural Organization (FAO), CABI and Scopus
Journal of Agricultural Extension

Vol. 23 (2) April, 2019

ISSN(e): 24086851; ISSN(Print); 1119944X

http://journal.aesonnigeria.org

http://www.ajol.info/index.php/jae

Email: editorinchief@aesonnigeria.org

http://eoi.citefactor.org/10.11226/v23i2

Sankoh, A.I., Whittle, R., Semple, K.T., Jones, K.C., Sweetman, A.J., (2016). An Assessment of the Impacts of Pesticide Use on the Environment and Health of Rice Farmers in Sierra Leone. Environment International, 94: 458-466. https://doi.org/10.1016/j.envint.2016.05.034

Stadlinger, N., Mmochi, A.J. \& Kumblad, L. (2013). Weak Governmental Institutions Impair the Management of Pesticide Import and Sales in Zanzibar. AMBIO, 42 (1): 72-82. https://doi.org/10.1007/s13280-012-0338-6

Sumarno and Suyamto. (2014). Budidaya Padi Ramah Lingkungan dan Berkelanjutan. Prosiding Analisis Ketersediaan Sumberdaya Pangan dan Pembangunan Pertanian Berkelanjutan. Badan Penelitian dan Pengembangan Pertanian. Jakarta.

Ville Saint, A.T., G. M. Hickey and L. E. Philip. (2017). Institutional Analysis of Food and Agriculture Policy in the Caribbean: The Case of Saint Lucia. Journal of Rural Studies, 51:198-210.

Wilkinson J., C. Cerdan and Dorigon C. (2015). Geographical Indications and "Origin" Products in Brazil. The Interplay of Institutions and Networks. World Development. 0305-750X/2015 Elsevier Ltd. ARTICLE IN PRESS.

Yuantari, C., Kresnowati, L., and Hartini, E.,(2015). Rumusan Strategi Kesehatan dan Pertanian Dalam Percepatan Pengentasan Kemiskinan Menuju Tercapainya Target MIDGS 2015. Prosiding Seminar Nasional Banjar Negara. Editor: Eny Sofiyatun, Jiko Malis Sunarni, Okti Hanayanti, dan Sapto Wibowo. Sukses Mandiri Press. Banjar Negara. Jawa Tengah. 